\title{
A note on centrifugation for improving freshwater invertebrate sample conservation
}

\author{
ANTONIO G. VALDECASAS, ${ }^{1}$ RICARDO GARCÍA-JIMÉNEZ, ${ }^{2}$ \\ MERCEDES MARÍN F.-CAMPOAMOR ${ }^{3}$
}

\footnotetext{
${ }^{1}$ Museo Nacional de Ciencias Naturales, CSIC, José Gutiérrez Abascal, 2, 28006-Madrid, Spain, ORCID: 0000-0002-5665-4906

${ }^{2}$ Museo Nacional de Ciencias Naturales, CSIC, José Gutiérrez Abascal, 2, 28006-Madrid, Spain, ORCID: 0000-0002-3746-5456

${ }^{3}$ Paseo de la Chopera, 11. 28045 - Madrid. Spain, ORCID: 0000-0002-2100-1884

Corresponding author e-mail: valdeca@mncn.csic.es
}

Keywords live sorting, sampling trips, optimal sample conservation, benthos, streams

Abstract Sorting of freshwater invertebrate samples is best done while the animals are still alive. However, sorting in the field generally means less overall sampling can be done in the allotted time. Placing samples under cold conditions has been the traditional way to extend the life of the organisms contained within them. In this work, we evaluated whether the addition of a centrifugation step extends the survival time of organisms post-sampling, thus providing more time for sorting. Three salad spinners were tested for their capacity to extract water from samples. Additional observations were made on the compaction of samples due to excessive centrifugation. We conclude that adding a short centrifugation step of 30 seconds prolongs the life of several freshwater invertebrate taxa, including Hydrachnidia, Nematoda and Ostracoda. Furthermore, when fixation of samples in the field is necessary, centrifugation reduces the amount of fixative to be added to the samples to reach a certain concentration. Fixed samples can also be centrifuged, which may be particularly relevant when sampling abroad as inflammable liquids are often prohibited on planes. In our experience, centrifuging fixed samples does not compromise the fixed organisms, or their genetic material.

\section{Wskazówka dotycząca wirowania w celu uzyskania lepszej jakości prób bezkręgowców słodkowodnych}

Słowa kluczowe

sortowanie przeżyciowe, wyprawy badawcze, optymalna ochrona próbek, bentos, strumienie

Streszczenie

Sortowanie prób bezkręgowców słodkowodnych najlepiej wykonywać przeżyciowo, jednak sortowanie w terenie prowadzi na ogół do ograniczenia liczby wybieranych taksonów w wyznaczonym czasie. Umieszczanie próbek w niskich temperaturach jest tradycyjnym sposobem przedłużania życia zawartych w nich organizmów. W tej pracy oceniliśmy, czy dodanie etapu wirowania wydłuża czas przeżycia organizmów po pobraniu próbek, zapewniając tym samym więcej czasu na sortowanie. Trzy odsączarki do warzyw przetestowano pod kątem ich zdolności do ekstrakcji wody z próbek. Dodatkowe obserwacje dotyczyły zagęszczenia próbek w wyniku nadmiernego wirowania. Doszliśmy do wniosku, że dodanie krótkiego, 
30 -sekundowego etapu wirowania przedłuża życie kilku taksonów bezkręgowców słodkowodnych, w tym Hydrachnidia, Nematoda i Ostracoda. Ponadto, gdy konieczne jest utrwalenie próbek w terenie, wirowanie zmniejsza ilość środka utrwalającego dodawanego do próbek, aby osiągnąć określone stężenie. Utrwalone próbki można również odwirować, co może być szczególnie istotne w przypadku pobierania próbek za granicą, ponieważ płyny łatwopalne są często zabronione w samolotach. Z naszego doświadczenia wynika, że wirowanie utrwalonych próbek nie zagraża utrwalonym organizmom ani ich materiałowi genetycznemu.

\section{Introduction}

In any study of freshwater fauna, sorting of organisms is usually one of the more time consuming activity besides classification. The time required to sort organisms is dependent on their size, color and mobility. Ideally, sorting would occur in the field while the organisms are still alive and time is not limited. Under these circumstances, the organisms are often still moving around and, thus, are more easily detected. In addition, the most optimal fixative can be used according to the organism sorted (for a detailed list of preferred fixatives for different invertebrate taxa, see Table 4 in Valdecasas et al., 2010). However, sampling often does not occur under ideal conditions. Generally speaking, during a typical sampling effort, particularly those that occur abroad, several samples have to be taken in short periods of time and a generalized fixative must be used for sample preservation (Hauer, Resh, 2006).

Commonly suggested methods for the conservation or fixation of freshwater benthic samples include, among others, filling a glass or plastic jar no more than $1 / 3$ of its capacity and keeping it cold until reaching the lab (Schwoerbel, 1970) or adding $40 \%$ formaldehyde to a sample until reaching a final concentration of 1\% (e.g. Tachet, 2000) or 4\% (e.g. Andreu, Camacho, 2002). Notably, some authors explicitly mention the carcinogenic properties of formaldehyde, whereas other do not. In both cases, it was suggested that the fixative be exchanged for ethanol upon arrival to the lab or, at most, within a couple of days. Another common fixation strategy is to add $95 \%$ ethanol to a sample jar until a concentration of approximately $75 \%$ (Hauer, Resh, 2006). In many other publications, fixatives are not mentioned and animals were sorted in the lab, supposedly close to the sampling sites or without a special treatment (e.g. Stryjecki et al., 2018). Nowadays, ethanol is the favored fixative for all kinds of organisms as ethanol-preserved samples can be processed for molecular analyses (e.g. DNA extraction and sequencing).

The study of some aquatic micro- and macroinvertebrates, however, may require them to be alive for certain analyses in the laboratory. In addition, duplicates are often required for morphological and molecular studies of some taxa like Turbellaria. Transporting large volumes of benthic aquatic invertebrate samples to the laboratory is not only cumbersome but also problematic due to changes in water temperature and damage to specimens. Invertebrates confined to small spaces tend to interact, resulting in the loss of structures such as gills and legs, or they simply die in transit. On the other hand, sorting in the field is very time consuming, which may restrict a greater sampling effort.

For the last several years, we have been using a centrifugation method that is simple, effective, and inexpensive. This method also saves on the amount of generalized fixatives needed to be brought to the field, in the event samples need to be fixed. For samples not fixed in the field, it increases the chance that many more organisms will arrive to the lab alive, and generally with better body conditions. Our method uses a salad spinner to squeeze out sample liquid. We hypothesize that, based on the higher thermal transmission of water than air, greatly reducing 
the volume of water in a sample jar may allow the freshwater invertebrate organisms to survive longer post-sampling, which may help prolong the time available for their sorting.

In this note, we evaluate parameters of three types of salad spinners, and additional materials and methods used for the centrifugation of benthic microinvertebrate samples in the field, including centrifugation time. We also assess the post-sampling survival of several invertebrate taxa over time.

\section{Material and methods}

\section{Types and evaluation of salad spinners}

There are four main types of salad spinners: pull cord, push bottom, crank operated, and electric, and for each category, there are different sizes and volumes. For this study, we excluded electric spinners as they are not practical for field work. Figure 1 shows the three spinners analyzed plus additional material used in the study.

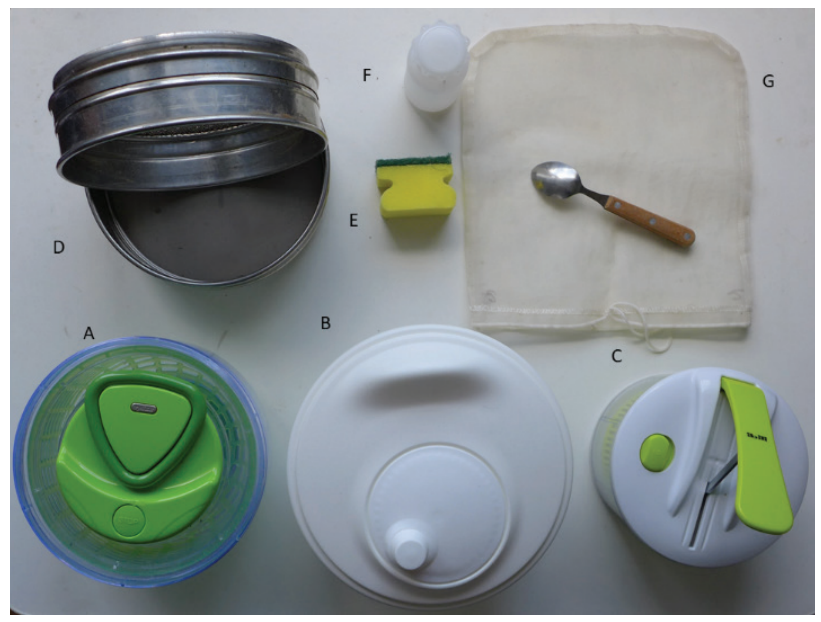

A - pull-cord spinner; B - crank-operated spinner; C - push-bottom spinner; D - two metal sieves with a mesh size of $3.2 \mathrm{~mm}$ and $0.250 \mathrm{~mm}$, respectively; E - sponge; F - 125-ml plastic jar; G - $0.200 \mathrm{~mm}$ nylon mesh bag and spoon.

Figure 1. The three types of salad spinners and additional material used in the study

The power of a spinner to extract liquid can be evaluated by the $\mathrm{g}$ force it applies over its contents. The $\mathrm{g}$ force is dependent on spinner speed and the radius of the rotating part. The diameter of the rotating part of the spinners tested was $18 \mathrm{~cm}(\mathrm{r}=9)$ for the pull cord, $14 \mathrm{~cm}(\mathrm{r}=7)$ for the push bottom and $20 \mathrm{~cm}(\mathrm{r}=10)$ for the crank operated. The following equation was used to calculate the $\mathrm{g}$ force of each spinner:

$$
\mathrm{g}=\left(1.118 \times 10^{-5}\right) \mathrm{r} \times \mathrm{RPM}^{2}
$$


where $r$ is the radius of the rotating part and RPM is the revolutions per minute. To compare the three spinners, we used the maximum RPM, which was measured with a Pyle PLT26 laser tachometer.

We then used a set of equivalent Scotch-Brite sponges (green fiber scourer) to test the liquid extraction abilities of the different spinners, taking into account the $g$ force of each spinner. For each spinner, five similarly sized pieces of sponges (15 in total) were repeatedly soaked in water. They were then allowed to drain freely without pressure before being put into the spinner. Each spin was carried out in two steps: sponges were spun for 30 seconds, then the water was removed from the spinner before another 30 -second spin. Each sponge piece was weighed before and after spinning on a Smart Weight balance, model TZ 5000. The water extraction parameter was expressed as the percentage difference in weight between wet and spun sponges.

To statistically compare results from the three spinners, an ANOVA was carried out online at the VassarStats website (http://vassarstats.net/anovalu.html, accessed 22.05.2020).

\section{Procedure in the field}

Five benthic samples were taken from a gravel bottom mountain stream by kick sampling using a circular net with a $30-\mathrm{cm}$ mouth diameter, $0.250-\mathrm{mm}$ mesh, and $80-\mathrm{cm}$ net length (Figure 2). The samples were filtered first through a $3.2 \mathrm{~mm}$ metal sieve followed by a $0.250 \mathrm{~mm}$ sieve.

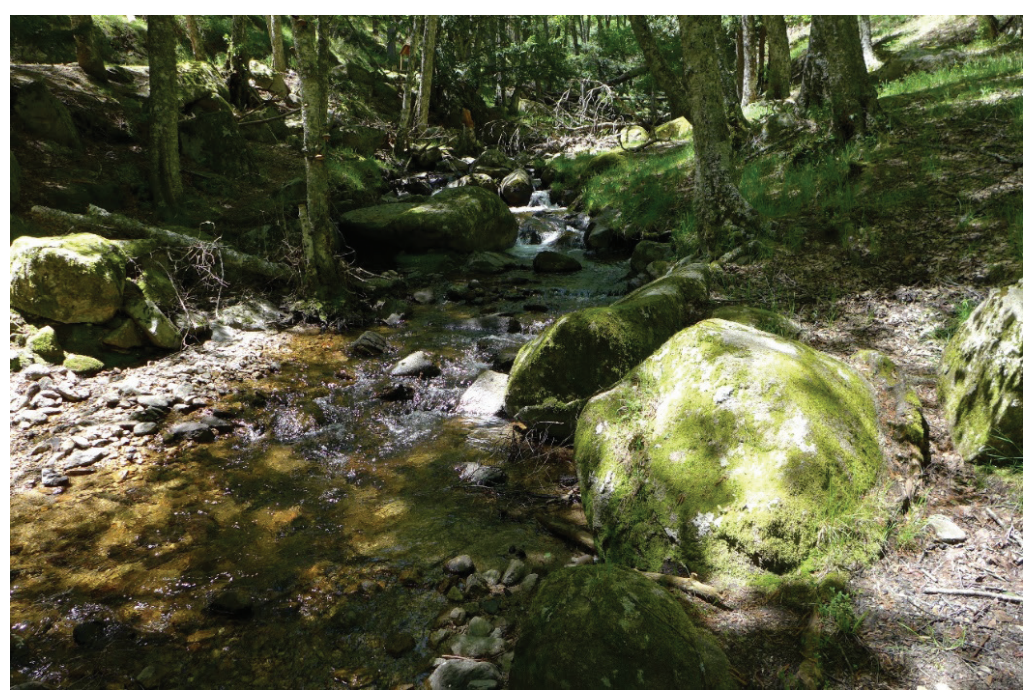

Figure 2. Field sampling site, Canencia stream (Madrid)

The organisms in the upper sieve were easily visible to the naked eye and were not centrifuged. The contents of the finer sieve were divided in two approximately equal parts. One part was transferred to a plastic jar and placed inside a cool box with ice. The second part was transferred to a 200- $\mu$ m nylon monofilament bag, placed into a pull-cord spinner, and spun twice for $30 \mathrm{sec}$ each time, after which the contents of the bag were transferred to a $125-\mathrm{ml}$ plastic jar. All the 
samples were kept cold in a cool box while in the field prior to being transferred to a fridge once in the lab. Maximum and minimum temperatures were measured in the cool box during the trip and in the fridge during the post-sampling analysis with a max/min digital thermometer. Both sets of samples, non-centrifuged and centrifuged, were checked daily: a small amount from each was transferred to a petri dish filled with river water up to height of $5 \mathrm{~mm}$ and the contents viewed under a Nikon stereomicroscope. Live and dead specimens of the different animal groups were counted and categorized as either 1) almost all alive; 2) more alive than dead; 3) more dead than alive; 4) all dead or 5) not observed.

Each petri dish was reviewed several times under different backgrounds (black and white) and powers $(10 \times$ and $18 \times)$.

To evaluate whether a single short spin would affect sample compaction, another two samples were each split into two nearly equal parts and one part was centrifuged with the pull-cord spinner and the other with the push-bottom spinner, both for only 30 seconds. Finally, as a control, two additional samples served as centrifuged and non-centrifuged replicates kept at ambient temperature. These samples were collected, split into two parts and treated as described above for the five benthic samples.

\section{Results}

\section{Spinner type evaluation}

We measured several parameters, including the mean RPM, g force and percentage of water extraction, for each of the spinners, i.e. pull cord, push bottom, and crank operated (Table 1).

Table 1. Parameters of the three spinners evaluated in the study

\begin{tabular}{|l|c|c|c|}
\cline { 2 - 4 } \multicolumn{1}{c|}{} & A & B & C \\
\hline Radius $(\mathrm{cm})$ & 9.00 & 7.00 & 10.00 \\
\hline Mean RPM & $1,162.00$ & 999.00 & 679.00 \\
\hline G force & 135.86 & 78.10 & 51.50 \\
\hline Percent Water Extraction & 77.06 & 70.50 & 70.30 \\
\hline
\end{tabular}

$\mathrm{A}$ - pull-cord; B - push bottom and C - crank operated. RPM, revolutions per minute.

The mean RPM value for each spinner was calculated as the mean of three measurements taken of each empty spinner. The mean percentage of water extraction for the three spinner types was $77.0 \%$ for the pull cord, $70.5 \%$ for the push bottom, and $70.3 \%$ for the crank operated. There was a significant effect of the pull-cord spinner over the other two $(\mathrm{F}(5.5)=5.83, \mathrm{p}=0.017)$. The percentage of water extraction for the push-bottom and crank-operated spinners were not significantly different from each other.

\section{Field samples}

Figure 3 summarizes the survival of the different taxa found in the five centrifuged or noncentrifuged samples $24 \mathrm{~h}$ up to $96 \mathrm{~h}$ post-sampling. 

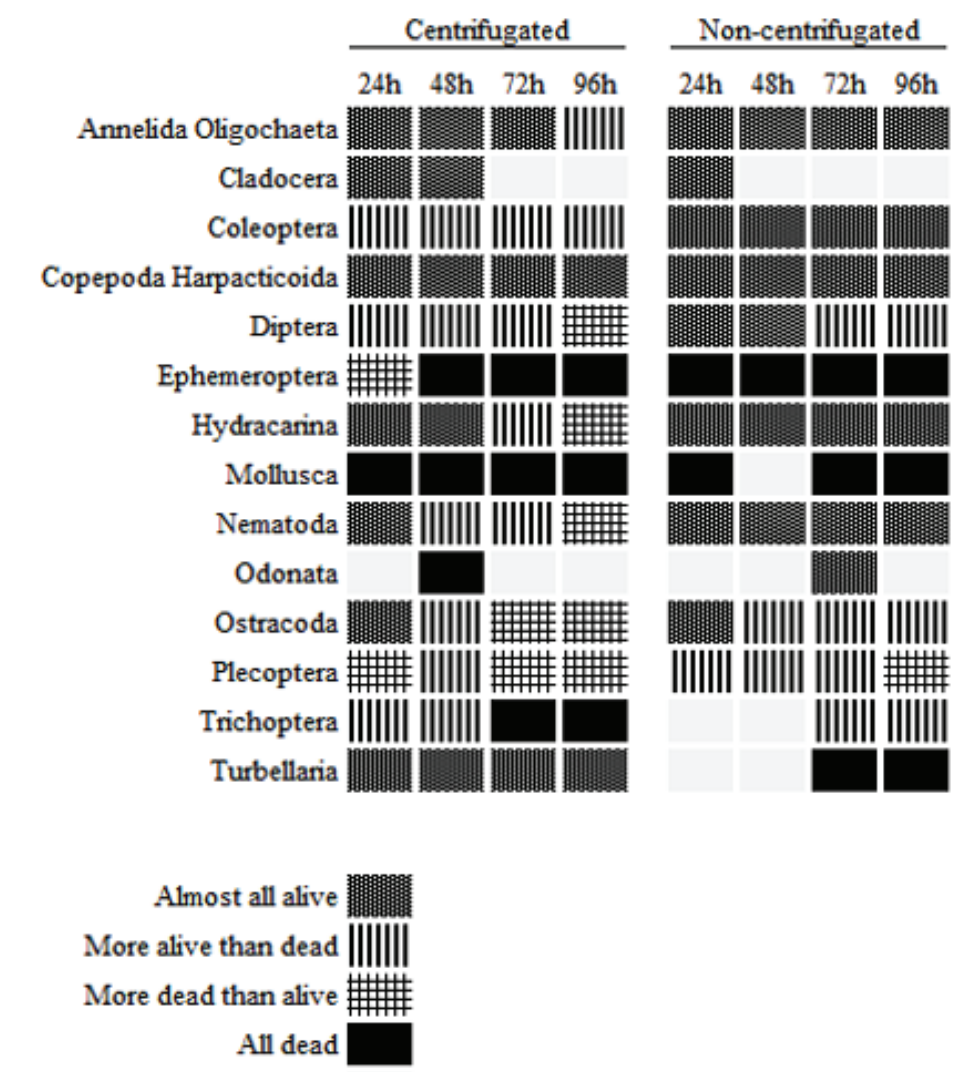

Not observed in any of the

5 petri dishes

Figure 3. Summary of the differential survival of taxa in centrifuged versus non-centrifuged samples kept at $6^{\circ} \mathrm{C}$ over a period of 4 days

These samples were all kept at about $6^{\circ} \mathrm{C}$ in both the field and the lab. As shown in Figure 3, there is a substantial improvement in the overall survival of benthic invertebrate taxa with centrifugation, except for Ephemeroptera and Mollusca, which had all died in the first 24 hours. Oligochaeta, Coleoptera (larvae and adults), Harpacticoida, Hydrachnidia (water mites), and Nematoda were the most robust taxa over the 96-h post-sampling period. Of these, Hydrachnidia and Nematoda showed the most improvement, in terms of survival, whereas the others were relatively hardy in both sets of samples. In fact, water mites were one of the most resistant taxa analyzed in our study as plenty of live animals were seen in the centrifuged samples $312 \mathrm{~h}$ postsampling. This enabled us to sort for live specimens for a longer period of time compared with the other taxa. Survival of Diptera and Ostracoda was also enhanced with centrifugation. Live Turbellaria were found in the non-centrifuged samples over the duration of the post-sampling period; however, in the centrifuged samples, they were either all dead or not observed. By contrast, in the samples centrifuged only once for 30 seconds, Turbellaria were found alive and 
wandering (data not shown), suggesting that the higher compaction of the longer centrifugation was detrimental to their survival. In summary, we observed that the morphological conservation of most taxa, excluding Turbellaria which required a shorter centrifugation time, was better with centrifugation (either long or short).

Compaction of samples was evaluated qualitatively by eye when we were preparing the sample subsets for observation in petri dishes. In the double centrifuged samples, we observed some compaction. Lumps were split either with needles or by agitating the sample subset with a small amount of water in a vial prior to observation. No lumps were observed in the samples centrifuged only once with either the pull-cord or the push-bottom spinner. Even more, Turbellaria, which formed lumps and were dead in the double centrifuged samples, were seen wandering around in the single centrifuged samples.

The macroinvertebrates in the benthic samples kept at ambient temperature, which reached a maximum of $24^{\circ} \mathrm{C}$, were almost all dead, regardless of whether they were centrifuged or not.

\section{Discussion}

Classic and recent publications on the sampling and sorting of aquatic invertebrates emphasize the convenience of sorting live organisms (Anderson et al., 2013). Small organisms can be more easily detected when moving. Indeed, the human eye can see particles smaller than 0.04 $\mathrm{mm}$ if they are in motion (Kalloniatis, Luu, 2007). Size and color (at least, those that contrast with the background) are additional factors that aid detection. The dilemma is how to balance time spent sampling versus sorting in the field. More time spent sampling in the field often necessitates taking live samples to the lab for sorting. This is particularly true when a sampling trip involves sampling several different localities before returning to the lab.

This work deals with sample conservation prior to sorting, which itself has been treated extensively in the specialized literature (e.g. Valdecasas et al., 2010 and references therein). Given that live, mobile organisms are easier to detect than dead ones, we tested whether centrifuging samples in the field prior to sorting improves the survival of the organisms contained within them, which, in turn, would extend the time available for sorting live organisms. In both centrifuged and non-centrifuged samples, keeping them at a low temperature appears to be a critical factor for survival as evidenced by the poor survival of samples kept at ambient temperature.

We suggest that the main reason for the difference in the survival of organisms between centrifuged and non-centrifuged samples is the higher thermal conductivity of water versus air (approximately 0.6 vs $0.025 \mathrm{~W} /(\mathrm{mK})$; https://www.engineeringtoolbox.com/thermal-conductivityd_429.html, accessed on 25.05.2020). In this sense, centrifugation helps to better preserve the specimens in cold temperatures. We did not measured putrefaction, but the non-centrifuged samples kept at a low temperature smelled bad earlier than the centrifuged ones, suggesting they had started to decay first. Also, consistent with the idea that samples should be kept cold, organisms in the centrifuged and non-centrifuged samples kept at ambient temperature, which was relatively high during the post-sampling period (about $24^{\circ} \mathrm{C}$ ), all died within the first 24 hours.

A long centrifugation could be counter-productive as it may excessively compact the substrate in the sample. According to the parameters of the spinners analyzed, either of the two spinner sizes tested with the short centrifugation (i.e. the pull cord or push bottom) would be adequate for use in the field. In our many years of experience, the smaller spinner size (e.g. $r=7$ ) has proven sufficient for our purposes. Given that baggage space is usually limited on many sampling trips, its smaller size is particularly relevant. We recommend a single centrifugation step of about 
30 seconds in order to extract a substantial amount of water from the sample without excessive compaction. The centrifugation time may be modulated depending on the specific taxa of interest.

Below, we provide a brief summary of the applications of centrifugation of benthic freshwater invertebrate samples from our experience:

1. We have used this method with success mainly on samples collected in mountain streams and flowing water with mixed gravel sediments. In our experience, it is not ideal for samples taken from the muddy bottom of ponds or pools, or from water that has an abundance of filamentous floating algae, as the samples become highly compacted after centrifugation.

2. The sieve and bag mesh size to use during sampling depends on the organisms and/or life cycle stages under study. We typically work with a $250-\mu \mathrm{m}$ mesh stream net, but smaller mesh sizes may be used, if desired.

3. Notably, there is a big difference between centrifugation, which gently compresses the material and organisms contained in a sample, and squeezing the nylon bag by hand, which usually distorts or breaks the organisms' body structures.

4. When samples need to be fixed in the field with ethanol, a centrifugation step will save on the amount of fixative needed to reach the recommended ethanol concentration, which is usually $70 \%$ or more.

5. An interesting and relevant consideration is the transportation of samples by plane. Many airlines prohibit transporting ethanol at concentrations greater than $70 \%$ in checked baggage. The spinners allow the alcohol to be drawn out from the sample before departure. The samples can then be refilled as soon as reaching lab. We have not observed detectable differences in the extractability of genetic material (DNA) using this method (GarcíaJiménez et al., 2017).

\section{Conclusions}

Centrifugation of benthic invertebrate samples has the following advantages:

- it is less damaging for delicate animals compared with hand squeezing samples in nylon monofilament bags,

- organisms in centrifuged samples kept at a low temperature usually live longer,

- it is a simple and inexpensive yet efficient method,

- centrifuging samples may reduce the amount of ethanol needed per sample either for routine fixing or to avoid transporting inflammable liquids on planes.

\section{Acknowledgements}

Bruno G. Valdecasas provided assistance during the work and Melinda Modrell revised the English language on a previous draft of this manuscript. 


\section{References}

Anderson, J.T., Zilli, F.L., Montalto, L., Marchese, M.R., McKinney, M., Park, Y.L. (2013). Sampling and Processing Aquatic and Terrestrial Invertebrates in Wetlands. In: J. Anderson, C. Davis (eds.), Wetland Techniques. Dordrecht, The Netherlands: Springer.

Andreu, E., Camacho, A. (2002). Recommendations for sampling water, biota and bottom sediments in Ramsar wetlands (bilingual Spanish-English). Madrid: Ministerio de Medio Ambiente.

García-Jiménez, R., Horreo, J.L., Valdecasas, A.G. (2017). Minimal barcode distance between two water mite species from Madeira Island: a cautionary tale. Experimental and Applied Acarology, 72, 133-143. DOI: 10.1007/s10493-017-0147-5.

Hauer, F.R., Resh, V.H. (2006). Macroinvertebrates. In: F.R. Hauer, G. Lamberti (eds.), Methods in Stream Ecology (chapter 20). Academic Press.

Kalloniatis, M., Luu, C. (2007). Visual Acuity by Michael Kalloniatis and Charles Luu. Webvision. The Organization of the Retina and Visual System, 5. Retrieved from: https://webvision.med.utah.edu/ book/part-viii-psychophysics-of-vision/visual-acuity.

Schwoerbel, J. (1970). Methods in Hydrobiology. Pergamon Press.

Stryjecki, R., Bankowska, A., Szenejko, M. (2018). A faunistic and ecological characterization of the water mites (Acari: Hydrachnidia) of the Bukowa River (central-eastern Poland). Acta Biologica, 25,77-94.

Tachet, H. (2000). Invertébrés d'eau douce. Sytematique, biologie, ecologie. Paris: CNRS editions.

Valdecasas, A.G., Aboal, M., Cirujano, S., Iepure, S., Jaume, D., Proctor, H., Velasco, J. L. (2010). Sampling continental freshwater. In: J. Eymann, J. Degreef, C. Häuser, J.C. Monje, Y. Samyn, D. Vandenspiegel (eds.), Manual on Field Recording Techniques and Protocols for All Taxa Biodiversity Inventories (pp. 213-272). Abc Taxa cap. 10.

Cite as: Valdecasas, A.G., García-Jiménez, R., Campoamor, M.M.F. (2020). A note on centrifugation for improving freshwater invertebrate sample conservation. Acta Biologica, 27, 21-29. DOI: 10.18276/ ab.2020.27-03. 